\title{
Article \\ Stabilization Methodology in Foundation Soils by ERT-3D Application in Estepona, South Spain
}

\author{
Alfonso Gutiérrez-Martín ${ }^{1, *(\mathbb{D})}$, José I. Yenes $^{2}\left(\mathbb{D}\right.$, Marta Fernández-Hernández ${ }^{3,4}\left(\mathbb{D}\right.$ and Ricardo Castedo ${ }^{4}(\mathbb{D}$ \\ 1 Escuela Técnica Superior de Arquitectura-Universidad de Málaga, 29071 Málaga, Spain \\ 2 Escuela Politécnica Superior del Ejército, (ESPOL), 28002 Madrid, Spain; jyengal@et.mde.es \\ 3 Instituto Geológico y Minero de España-IGME, 28003 Madrid, Spain; m.fernandez@igme.es or \\ marta.fernandezh@alumnos.upm.es \\ 4 ETSI Minas y Energía, Universidad Politécnica de Madrid, 28003 Madrid, Spain; ricardo.castedo@upm.es \\ * Correspondence: alfgutmar@uma.es
}

check for updates

Citation: Gutiérrez-Martín, A.;

Yenes, J.I.; Fernández-Hernández, M.; Castedo, R. Stabilization

Methodology in Foundation Soils by ERT-3D Application in Estepona,

South Spain. Appl. Sci. 2021, 11, 4455. https://doi.org/10.3390/app11104455

Academic Editor: Daniel Dias

Received: 13 April 2021

Accepted: 11 May 2021

Published: 13 May 2021

Publisher's Note: MDPI stays neutral with regard to jurisdictional claims in published maps and institutional affiliations.

Copyright: (c) 2021 by the authors. Licensee MDPI, Basel, Switzerland. This article is an open access article distributed under the terms and conditions of the Creative Commons Attribution (CC BY) license (https:// creativecommons.org/licenses/by/ $4.0 /)$.
Featured Application: A non-invasive solution developed to preserve damaged buildings using an injection of cement grout in the soils to stabilize it.

Abstract: The paper proposes a novel methodology for the stabilization of shallow foundations, with a simplified model combined with 3D electrical resistivity tomography (ERT-3D and consolidation injections. To determine its usefulness, the method has been applied in a case located in Estepona (southern Spain). The chosen tomography model is the dipole-dipole configuration, with an optimized distance between electrodes of $0.80 \mathrm{~m}$ for a better visualization of the foundation subsoil; with this parameterization, a total of 72 electrodes were installed in the analyzed case. In this work, the depth of the anomaly in the building's supporting subsoil was detected ranging from $2.00 \mathrm{~m}$ to $3.90 \mathrm{~m}$ deep. The study also delineates areas of high resistivity variations (50-1000 $\Omega \mathrm{m}$ ) in the middle and eastern end of the field. These data have been validated and corroborated with a field campaign. The results of the ERT-3D monitoring are presented, once the investment data has been processed with the RES3DINV software, from the beginning to the end of the stabilization intervention. The novelty occurs with the interaction between the tomography and the foundation consolidation injections, until the final stabilization. This is a very useful methodology in case of emergency consolidation, where there is a need to minimize damage to the building. Thus, people using this combined system will be able to practically solve the initial anomalies of the subsoil that caused the damages, in a non-invasive way, considerably lowering the value of the resistivities.

Keywords: electric tomography; three-dimensional; electrodes; seat control; foundations; stabilization methodology

\section{Introduction}

The success of architectural structures, which are built directly on the earth's surface, depends, among other factors, on the support offered by the foundation materials bearing the structures' loads [1-6] In turn, the ability of a building's foundation to offer the necessary support for architectural structures depends on the bearing capacity of the soils underneath, and, if the upper layer has heterogeneous physical properties, it could cause spatial variability in the foundation material's strength. Spatial variability of the soil's bearing capacity puts stress on poorly supported architectural structures. Associated structural failure could occur as total, partial, or differential settlement, or even total collapse of the structure, with differential settlement in the foundations being one of the worst problems [7-10].

The global prevalence of failure and collapse, with the associated loss of life and property, has made it necessary to ensure that buildings are properly constructed [11]. It is common to find many stress-induced cracks and other defect-related issues due to 
the various structures and foundations of historic, public, and private buildings, and some of these problems are disasters in the making [12-14]. This necessitates proposing a non-invasive intervention methodology for the subsoil of these buildings to avoid collapse.

One of the most used non-invasive techniques for subsoil exploration is geophysics and, more specifically, electrical resistivity tomography, in both two and three dimensions [15-21], and metrological perspectives of tomography in civil engineering [22]. In recent years, this method has proven to be an efficient tool, not only to monitor wall degeneration [23], but also to detect other types of problems in building foundations, such as subsoil degradation $[14,24,25]$. Spatial variability in load-bearing rock/soil beneath a building puts stress on poorly supported structures, causing failure $[10,26]$. Therefore, a geophysical investigation offers a faster, non-invasive means of obtaining detailed, credible information about the subsurface under a building. Electric tomography can also image the ground's distribution and structural deformation, both of which offer credible information regarding the strength the rock/soil is likely to offer a building $[24,27,28]$. Electrical resistivity imaging has, for decades, been very effective in illuminating the subsurface, and apt at providing information about the soil's physical properties for economic, environmental, and geological engineering. As mentioned, this technique is a useful and non-invasive method to diagnose subsoil problems in shallow foundations of buildings [3,29-32], which represent $25 \%$ of the claims reported in Spain, according to recent data provided by Aseguradora Mutua de Arquitectos Superiores, a public limited company (ASEMAS S.A.). However, the three-dimensional geophysical research approach ERT 3D [33-35] is better able than the two-dimensional approach ERT 2D to characterize the subsurface and determine heterogeneity in measured rock properties along the vertical $(Z)$ and orthogonal horizontal $(X, Y)$ axes [36,37].Thus, the determination of the variation in the soil properties along the three orthogonal directions would allow the evaluation of the spatial variation in the strength of the foundations, imposed by the heterogeneous properties of the soil [38].

Electrical resistivity tomography is an appropriate procedure for detecting and controlling underground consolidation and stabilization, specifically the ERT-3D tomography technique [39-42]. As mentioned above, the method consists of setting out parallel lines of observation, which cover the study area, to obtain underground data; however, the key point lies in processing the data. Fortunately, important advances have been made in 3D resistive imaging and its inversion processing through applying the powerful resistance inversion software, RES3DINV [43].This is possibly the most widespread, accurate, simple, and affordable software for data inversion in electrical tomography, and, thus, it has been used in this work. Several factors have been reported to impact the variation of electrical resistivity in the subsurface. These include variation in rock type, rock fabrics, rock deformation, water saturation, different degrees of weathering, etc. [44,45]. These factors, which are known to impact spatial variation on ground electrical resistivity, are also capable of impacting variation in other physical properties of rocks [46,47].With different electrode distances, ERT-3D offers the possibility of locating these gaps/cavities and possible holes under the foundation of a building, which can cause severe deformation and settlement. Both consolidating and stabilizing soil through injections have been proven effective [48-51] and are used to mitigate or even solve differential settling. The injection material generally depends on the lithological morphology of the soil in question. Synthetic resin is frequently used as an injection fluid [52], but this paper proposes injections of cement grout as a more economical and versatile solution.

For a soil consolidation project to be successful, electrical resistivity data must be available in advance to provide initial information on the subsurface structure. In our methodology for consolidating and stabilizing buildings with shallow foundations, we will use electrical tomography as a tool that detects empty cavities, which are typical examples of anthropic (resistive) fillings with low bearing capacity in subsoils [3]. Thus, this work proposes ERT -3D to monitor the subsoil in real time, from the beginning to the final consolidation through the different injection passes into the subsoil, until its stabilization. As an example of a case of application of our combined methodology, we have chosen a 
historic building with serious stability problems in its foundations [5], located in Estepona, on the Spanish south coast. The subsoil was consolidated with injections of cement grout applying the electrical methodology, resulting in the preservation of the building, and avoiding its possible collapse.

\section{The Model Development}

The ERT method discharges an electric current into the ground and measures the potential difference at two determined points on the surface. The suitability of this method lies in the fact that irregularities in the subsoil beneath a building can be identified as contrasts or anomalies in the subsoil's electrical properties.

This method is based on Ohm's law:

$$
\mathrm{Pa}=\mathrm{k}(\Delta \mathrm{V} / \mathrm{l})
$$

where: $\mathrm{Pa}=$ apparent resistivity [36]; $\mathrm{k}=$ geometric constant that depends only on the reciprocal positions of the current and potential electrodes; $\Delta \mathrm{V}=$ potential difference; $1=$ intensity of the injected current.

The apparent values of resistivity depend on the real resistivity distribution in the tested area. The true resistivity distribution can be estimated through a reverse procedure, based on minimizing an adequate function $[15,39,44]$. The solution to this problem is not unique. For the same set of data, a wide range of models can calculate the same apparent resistivity values. A preliminary lithological analysis is usually carried out on the subsoil's nature, to reduce the range of possible models, which can be incorporated into the reverse subroutine.

The solution method used minimizes the difference between the apparent resistivities measured and those calculated by the RES3DINV software, which uses the limited softness inversion formulation, restricting the model's change in resistivity values $[15,36,43,53]$. This study has used RES3DINVx64, which implements a smooth routine based on least squares and is practically the only commercial software of its type available $[36,54,55]$. The inversion routine used by the program is based on the smoothness-constrained leastsquares method [56]. The basic smoothness-constrained least-squares method is based on the following equation.

$$
\left(\mathrm{J}^{\mathrm{T}} \mathrm{J}+\lambda \mathrm{F}\right) \Delta \mathrm{q}_{\mathrm{k}}=\mathrm{J}^{\mathrm{T}} \mathrm{g}-\lambda \mathrm{F} \mathrm{q}_{\mathrm{k}-1}
$$

where:

$$
F=\alpha_{X} C_{X}^{T} C_{X}+\alpha_{Y} C_{Y}^{T} C_{Y}+\alpha_{Z} C_{Z}^{T} C_{Z}
$$

$\mathrm{J}^{\mathrm{T}}=$ Transpose of $\mathrm{J}$.

$\mathrm{J}=$ Jacobian matrix of partial derivatives.

$\lambda=$ Damping factor.

$\mathrm{q}=$ Disturbance vector.

$\mathrm{k}=$ Iteration number

$\mathrm{g}=$ Data mismatch vector.

$\alpha \mathrm{x}, \alpha \mathrm{y}, \alpha \mathrm{z}=$ weights for roughness filters

$\mathrm{Cx}, \mathrm{Cy}=$ horizontal roughness filters

$\mathrm{Cz}=$ vertical roughness filter

This method is advantageous because of its versatility since the damping and roughness factor filters adjust to the different types of data. This program uses the Gauss-Newton method, which recalculates the Jacobian matrix, after each interaction [57]. The interpretations of electrical tomography profiles are made using RES3DINVx64 [34,36] for resistivity and induced polarization. As mentioned above, this calculation software is based on the least-squares method with forced smoothing, modified with the Quasi-Newton optimization technique. The inversion method designs a subsoil model using rectangular prisms and determines the resistivity values for each of them, minimizing the difference between the apparent resistivity values observed $[15,58]$. The results of our model show an 
uncertainty in its acceptable magnitude. They are in a critical state with respect to their structural stability, load capacity and, under these conditions, the safety of the building's habitability. This is at an acceptable level of uncertainty associated with these increasing risks of instability [5].

\subsection{Application}

Some results reported in the literature and obtained in the last eleven years regard the application of the ERT-3D method to study geotechnical anomalies in the subsoils on slopes after landslides located in different geographical contexts.Such reports make us consider the ERT method as a tool and methodology very suitable to investigate these geotechnical anomalies of the subsoil during the pre-event and post-event phases of a disaster cycle [30,31,59-61] or simply a poor foundation support subsoil (anthropic fill).

In fact, during the pre-event phase, the resistivity contrasts that characterize ERT$3 \mathrm{D}$ allow defining the geological environment of the subsoil. They allow identifying areas of high-water content that could be responsible for reactivation events. In the post-event phase, ERT-3Denablesus to reconstruct the damaged or altered subsoil body by also providing information on the volume of the removed or altered material. This information can help to better plan future mitigation activities. Our original application not only detects these subsoil alterations in real time, but we also propose an original tool for subsequent mitigation, in case of affecting existing buildings or infrastructure in a non-invasive way and thus preventing their collapse.

One of the biggest drawbacks of 3D tomography for the investigation of shallow and disturbances in the subsurface was the fact that it did not provide continuous acquisitions over time, which made it unsuitable for the study of the dynamic nature of shallow and disturbances.

Fortunately, the development of systems for the continuous acquisition of electrical resistivity time and software for data inversion [61] are paving the way to test this method during the emergency phase, such as the application and methodology developed in the present work, where in real time we are applying the geoelectric investment data and carrying out the consolidation of the subsurface area, increasing its resistivity in the emergency case, and thus being able to recover existing constructions in the altered subsoil.

The possibility of using ERT-3D to monitor geotechnical changes and alterations in the first layers of a ground clearance-settlement area will add important information during the emergency phase. At this time, the preliminary results obtained in our methodology when applying the ERT-3D for this purpose are very encouraging. The proof of this is that we were able to recover the building that was based on the geotechnically altered substrate, where the grout cement, filler material proposed in our methodology for consolidating the subsoil, satisfactorily filled the gaps that water and air occupied in the altered substrate. Cement grout has advantages over other fillers, such as its economy, easy means of performing on site, ease of dosing, and versatility, among others.

In applying our methodology in these cases of emergencies where there is a removal of surface soil after a shallow of the subsurface that affects buildings and infrastructures [62,63], we have observed that a low resistivity zone lies in the upper area from the surface to a depth up to $4.00 \mathrm{~m}$, and the zone shows a higher resistivity of greater than $400 \Omega \mathrm{m}$. According to the data obtained in this work, the upper area of the soil unit consists of mostly silt soil with granule from the erosion of the bedrock. Therefore, we thought that the anomaly in the upper area is attributed to the silt soil and granule with low resistivity. This zone of low resistivity coincides with the zone of removal and presence of water, which we consolidated with our grout cement filling methodology and in real time the monitoring was carried out to verify the satisfactory level of the landfill.

The procedure followed by the authors clearly defines the altered surface material with cavities and gaps of the rocky matrix (phyllite) by lower resistivities in the bedrock (50-150 $\Omega \mathrm{m}$ ). This methodology characterizes the subsoil altered by shallow bedrock material mainly composed of (by) clay material (colluvial) with high pore-hole content and 
high resistivities. The modelling of the subsoil analyzed with our system was monitored with the ERT of the grout process using the 3D RESINV software [63]. Another novelty of our tool is the geological characterization of this type of shallow phenomenon, and its affectation to existing buildings on the slope that in the South of Spain, in La Cordillera Bética, occurs with recurrence [62-64]. To have a tool like this proposal to characterize and mitigate damage to existing buildings and infrastructures in a non-invasive way in this type of geological formation is an advantage.

The results after the application of the methodology in the case study showed the effectiveness of the diagnostic and intervention methodology for mitigating the serious damage suffered by the building, preventing the collapse and destruction of the building while preserving the safety of its inhabitants.

\subsection{Phases: Developed Methodology}

Anew methodology has been developed consisting of different phases and applied to the case study:

1. It is necessary to interpret the characteristics of the subsurface soil/rock in an electrical resistivity tomography methodology. The ERT-3D tomograms will show how subsurface materials affect the resistivity of the subsurface.

2. Using a geophysical method to boreholes will provide a detailed knowledge of the studied site, with no limits over analysis and misinterpretation.

3. This will delineate depths and thicknesses of subsurface layers and identify the stiffness and distribution of subsurface materials in the Baetic Mountain Range.

4. The electrical resistivity of metamorphic rocks in the Baetic Mountain Range (phyllite) is dependent on the degree of fracturing and the resistivity of the interstitial and pore water in the rock and its water content in such facture zones. Thus, the electrical resistivity ranges from 3000 of $\Omega \mathrm{m}$ to a fraction of $1.00 \Omega \mathrm{m}$.

5. Finally, a non-invasive system of filling of holes through the injection of cement grout in the subsoil will be applied, monitored in real time with the ERT and thus increase the resistivity of the subsoil, and with it, its consolidation.

\section{Case Study}

This research shows the results of applying the proposed methodology to a specific case of differential settlements in a building in anat-risk area after soil removal [5] - see Figure 1. The land movements occurred after heavy rains [64] in the 2009-2010 hydrological years, but measurements presented in this paper were taken in 2012.

The applied methodology is based on ERT-3D and consists of placing electrodes along profiles separated from each other according to the resolution, depth, and objectives to be covered. The lower the separation, the greater the resolution; the greater the separation, the greater the depth. An optimal distance of $0.80 \mathrm{~m}$. has been determined in our methodology between electrodes to obtain a balance between resolution tomographic profiles and depth in accordance with the problem in question.

Prior to performing the tomographic profiles, it is recommended that preliminary geological research be carried out in the area where the buildings are located [64]. In this case, the affected buildings were located at Paraje del Arroyo, La Cala, Estepona, Malaga (Spain), which is in the south of the Baetic Mountain Range (South Iberian Peninsula). The damage occurred at coordinates 36.461094, -5.160498 (Figure 1). In the first phase, it is proposed that a granulometric analysis and a Standard Penetration Test (SPT) be executed in the geotechnical surveys. In the present case, soil consistency increased with depth (Table 1). Change in the geotechnical response of the soil occurred at an approximate depth between one and four meters, according to the SPT hits along the analyzed sample (Table 1).

Note that the numbers in bold correspond to values that are too low. The grey background switching to white marks a discontinuity and an important change of capacity and bearing resistance in the subsoil, coincident with level I of Table 2. 


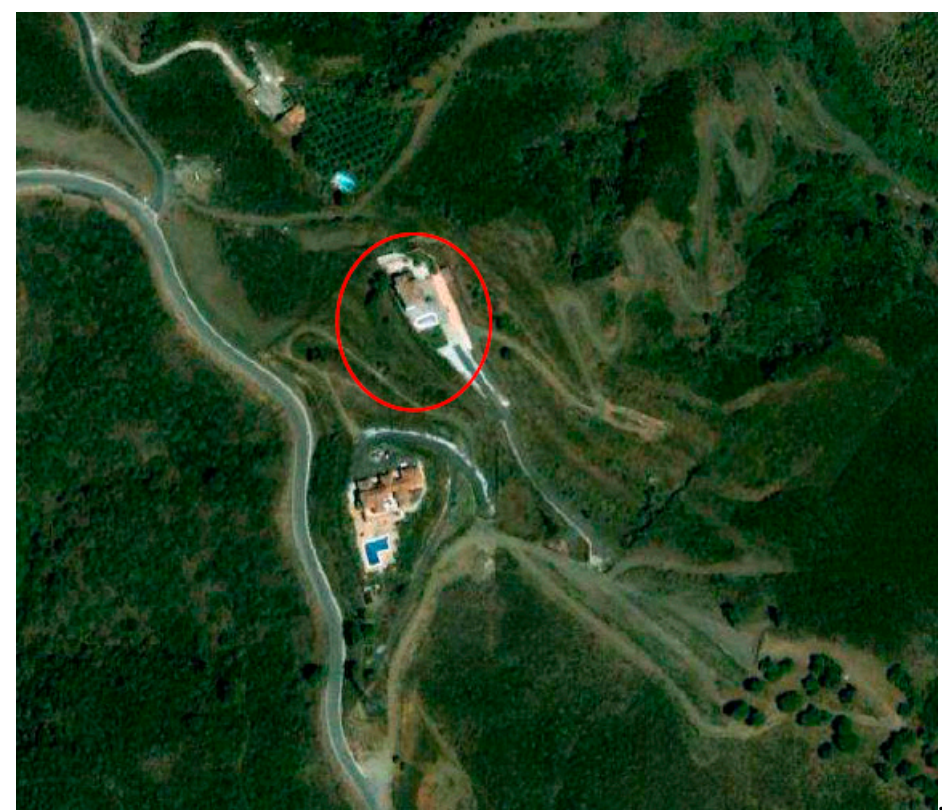

Figure 1. Aerial picture.Red circle: building location. April 2012.Source: geographical application Googlemaps/https:/ / www.google.com/maps/place (accessed on 25 April 2012), coordinates $36.461094,-5.160498$.

Table 1. Summary of the consistency and admissible stress of the soil according to the rotary probes. Measurements were taken at the height of the main facade of the most affected building.

\begin{tabular}{cccc}
\hline Depth (m) & Hit $\mathbf{N}_{\mathbf{2 0}}$ & Consistency & $\begin{array}{c}\text { Admissible Stress } \\
\left(\mathrm{KN} / \mathbf{m}^{\mathbf{2}}\right)\end{array}$ \\
\hline $\mathbf{0 . 0 0 - 1 . 0 0}$ & $\mathbf{4}$ & Soft & $\mathbf{3 0}$ \\
$\mathbf{1 . 0 0 - 2 . 0 0}$ & $\mathbf{3}$ & Soft & $\mathbf{2 0}$ \\
$\mathbf{2 . 0 0}-\mathbf{3 . 0 0}$ & $\mathbf{6}$ & Slightly hard & 40 \\
$\mathbf{3 . 0 0 - 4 . 0 0}$ & $\mathbf{7}$ & Slightly hard & $\mathbf{5 0}$ \\
$\mathbf{4 . 0 0 - 4 . 4 0}$ & $\mathbf{1 0}$ & Slightly hard & $\mathbf{7 0}$ \\
$4.40-6.00$ & 19 & Moderately hard & 120 \\
$6.00-7.00$ & 52 & Hard & 310 \\
$7.00-8.00$ & 63 & Hard & 350 \\
$8.00-8.60$ & 84 & Hard & 440 \\
\hline
\end{tabular}

Table 2. Lithography from the affected area via subsoil removal. Data are from lab tests. The depth of soil affected by lack of cohesion and similarity correspond with level I.

\begin{tabular}{ccc}
\hline Levels & Lithology & Depth $(\mathbf{m})$ \\
\hline I & Colluvial clay material & $0.00-4.40$ \\
II & Modified phyllites & $4.40-6.00$ \\
III & Phyllites & $6.00-25.00$ \\
\hline
\end{tabular}

Based on geological and geotechnical studies, the materials extracted in the area depict the lithological levels listed in Table 2. The analyzed soils were mainly rocky and clayey, of varying thickness, which could be verified in field work and through laboratory geotechnical tests.

\subsection{Damaged Building Analysis}

The most common deformations in a building are related to foundation differential movements. These alterations result in structural deformations in the building and angular distortions in its foundation $[3,65]$. This provokes stress throughout the construction, and when this stress limit is exceeded, cracking or breakages occur. 
The Spanish Building Technical Code (2006) defines the maximum angular distortion values for a building's ultimate limit of state and service, conditioning this value to the type of structure. In the service limit state, the allowable angular distortion value is $\mathrm{L} / 500$ for reticulated structures, and L/300 for isostatic structures and for load-bearing walls (the studied case). For L, the length in a straight line between the axes of the footings is analyzed. However, the structure's ability to assume these deformations will depend, among other factors, on the stiffness of each element comprising it, so any fixed distortion value could be conservative or give rise to non-tolerable deformations [66-69].

According to current urban regulations, the rural house examined in this study would be difficult to demolish and rebuild. Therefore, a major challenge to this research and methodology was finding a solution to recover the building without having to demolish it. The main building in this study was a rectangular two-story building, $17.15 \mathrm{~m}$ long and $12.05 \mathrm{~m}$ wide, with a surface area of approximately $206.66 \mathrm{~m}^{2}$ per floor and a total building area of $413.32 \mathrm{~m}^{2}$ (Figure 2).

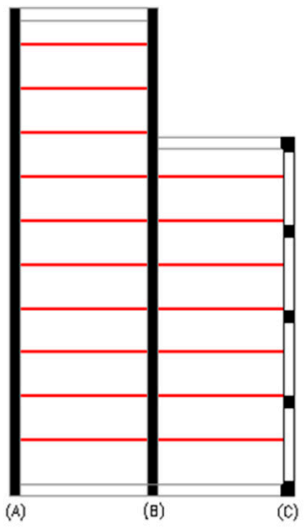

STRUCTURAL SHCEME

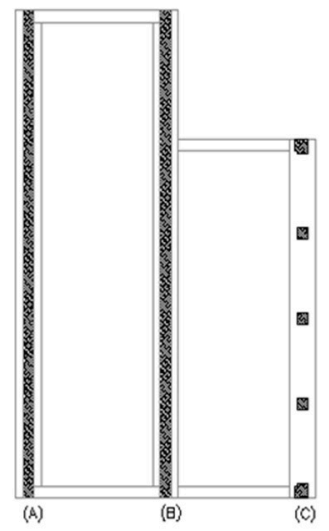

FOUNDATION SCHEME

a)

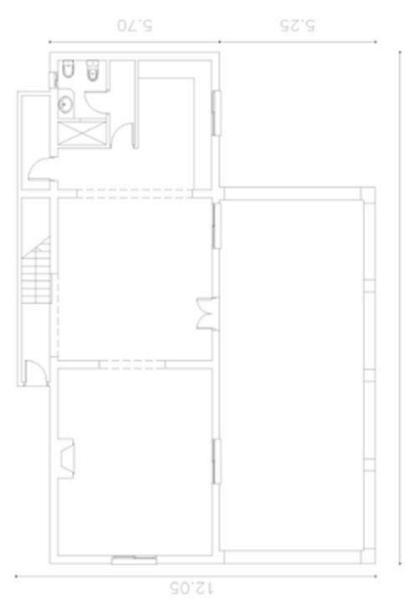

b)

Figure 2. (a) Structural scheme of the damaged building, formed by three load-bearing walls, A, B, and $C$, and forged of semi-resistant joists, $24 \mathrm{~cm}$ thick. Building foundation scheme formed by three parallel, longitudinal shallow foundations $(\mathrm{A}, \mathrm{B}, \mathrm{C})$, where the load-bearing walls rest and transmit the structure's weight. (b) Floor plan of the distribution of the damaged building in the slope.

This was a residential building and was used as a rural house (country holiday house); hence, guest and owner safety was paramount. The distribution comprised two building components: two floors, with an open area on the ground, and an upper, noble floor (Figure 2). Both the main building and the entrance foyer were designed in the late 1980s and completed in the early 2000s. The building's structure consisted of load-bearing walls and solid brick pilasters on the façade's main porch (vertical structure); these rested on a shallow foundation base of a reinforced concrete simple wall footing, formed by three parallel simple wall footings (A, B, C) (Figure 2). The horizontal structures of the building were $24 \mathrm{~cm}$ thick unidirectional slabs formed of semi-resistant joists, supported in three spaces by load-bearing walls and pilasters resting on a shallow foundation composed of three longitudinal foundations in a trench.

From the previous geotechnical and structural analysis of the building illustrated in Figures 2 and 3, a problem of support in the foundation for differential seats was deduced.

Of the $\mathrm{A}, \mathrm{B}$, and $\mathrm{C}$ foundations, $\mathrm{B}$ and $\mathrm{C}$ had become unstable (sunk downward) with respect to A (Figure 4). This phenomenon caused the building to swing forward, which caused serious damage to its structure, as can be seen in Figure 4. The foundation of wall A also suffered a small movement in its seat (S1) (Figure 4). 

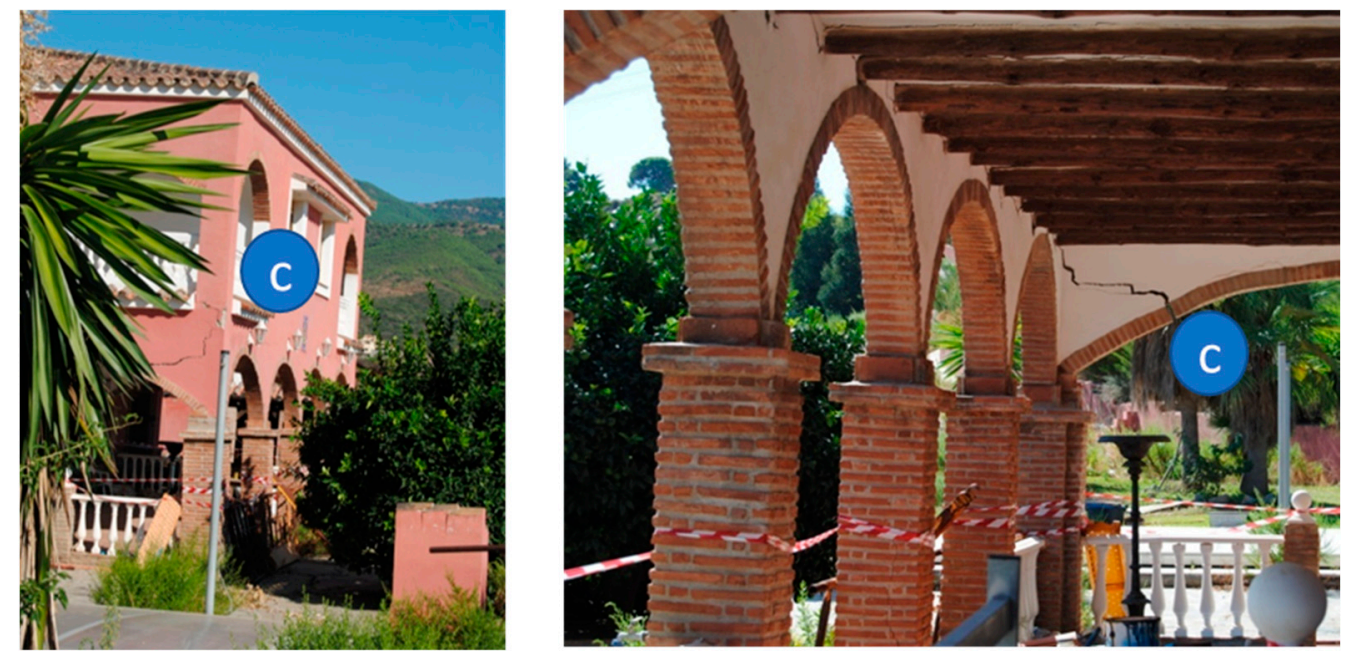

Figure 3. The building's state of conservation in April 2012, after the movement of the subsoil and its shallow foundation. (C-see Figure 2 for reference) Structure of load pilasters and semi-circular arches, a structure that has suffered a decrease in its foundation with respect to the foundations of the load-bearing walls (B) and (A) on Figure 2. This has caused the building to deform and rotate forward.

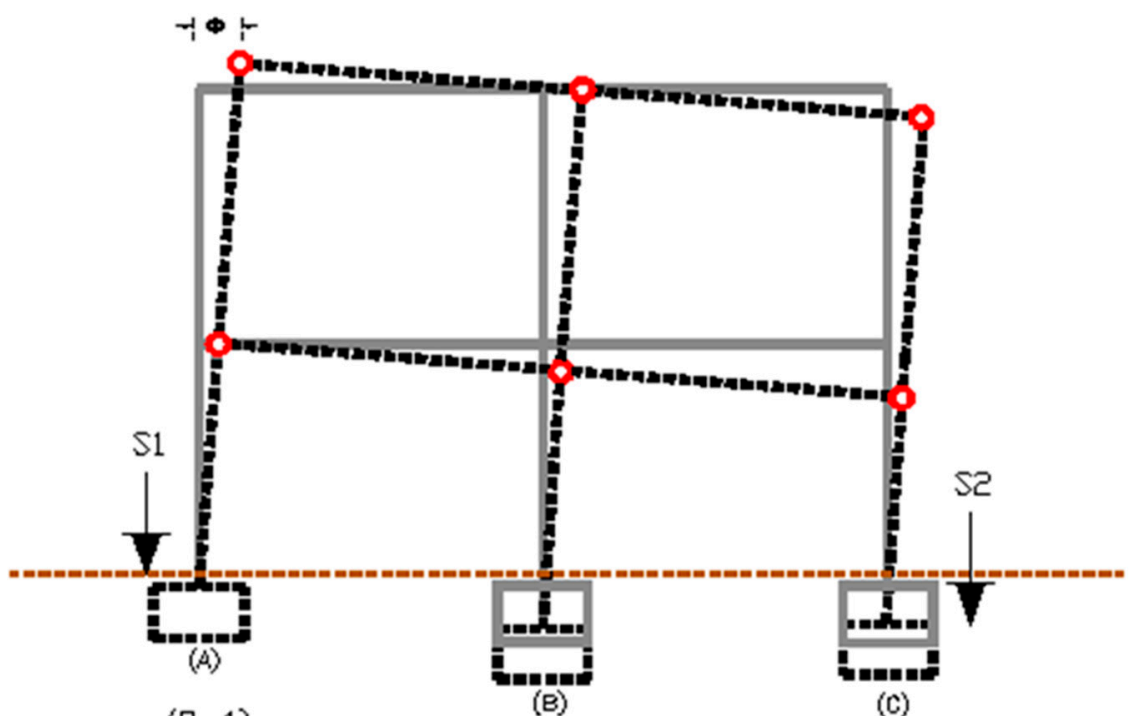

Figure 4. Cross-section scheme, presenting the likely behavior of the building's foundation and structure. There was a differential settlement of the S1 and S2 foundations due to a possible settlementremoval of the soil and the lack of bearing capacity of the resistant subsoil. Displacement occurred through the variable $\Phi=95 \mathrm{~mm}$, which is the depth B and C have descended, with respect to A. The seat of the foundation for wall A (S1) has lowered a depth of $25 \mathrm{~mm}$, remaining within the admissible limit according to the Spanish Building Technical Code (CTE).

Due to the type of movement and structural typology, displacement occurred as shown in Figure 4. When load-bearing walls deform, they collapse, and destruction of the building becomes a major threat.

To determine the building deformation as a function of the angular distortion, it was calculated as the differential settlement, defined as the settlement difference between foundations A and C, which were the extreme foundations affected by the settlements, 
applying the following equation. Knowing that in this case, it was the same height that has descended $B$ and $C$ with respect to $A$ :

$$
\delta_{A C}=S_{A}-S_{C}
$$

where $\delta_{A C}=$ foundation vertical differential displacement between points $\mathrm{A}$ and $\mathrm{C}$; $S_{A}=$ suffered differential settlement at point $\mathrm{A} ; S_{C}=$ suffered differential settlement at point $C$.

The equation of angular distortion is also applied [3,70-72]:

$$
\beta=\frac{\delta_{A C}}{L_{A C}}
$$

where: $\beta=$ angular distortion; $L_{A C}=$ distance between foundation points $\mathrm{A}$ and $\mathrm{C}$.

The Spanish Building Technical Code (2006), also known as CTE, establishes limitations on $\beta$ movements, according to building structure typology. Studies regarding $\beta$ began in the 1940s [73] and continue today [74-76]. The CTE limitation for the $\beta$ value, for building damages, must be $>\mathrm{L} / 300$ for load-bearing walls. In this case, the differential settlement between foundations $A$ and $C$ was $\delta_{A C}=95 \mathrm{~mm}$ and $\beta=0.0086$, which are above the admissible limit established by the CTE, indicating imminent building collapse.

Authors also link angular distortion $\beta$ values with damages suffered in enclosures (shell and internal partitions) and structural elements. The present case exceeded the limit values established by these authors, where the dimensions of cracks in enclosures must be $>25 \mathrm{~mm}$ to be considered a serious structural risk, according to a programmed damage classification [77]. As shown in Figure 4, this building had serious damage, due to cracks in enclosures and structural elements (load-bearing walls), which were measured at greater than $50 \mathrm{~mm}$. Therefore, according to this classification, the building was close to collapse. Due to the type of structure, foundation, and damages suffered, the methodology proposed in this research seems appropriate for the case. It would allow detection of zones of soil weakness where the differential settlement has been produced and consolidation of the subsoil from outside the construction, thus solving the building's issues non-invasively.

\subsection{Analysis and Stabilisation Methodology}

According to the data-regulations, the state of the building, the undeveloped land surrounding the building, and the necessity of keeping the building stable (i.e., avoiding imminent collapse) - a simplified model was proposed, in which ERT-3D would be used, with subsequent processing of the reversal data via the RES2DINV software [43], as seen in Figure 5. This analysis will consider the geotechnical data given in the previous sections.

The developed methodology allowed the researchers to see the reality of the soil, as well as any possible cavities in the subsoil supporting the building's foundation. These cavities were filled with grout to consolidate the soil, and then, via contrast campaigns (ERT-3D), the researchers checked to determine if the filling worked, if it moved, etc. Thus, the proposed methodology provided a complete, three-dimensional analysis of the subsoil supporting the damaged foundation, where the differential settlements occurred. Later, along with this original geophysical technique, the researchers monitored, through successive contrast campaigns, the consolidation and underpinning of the subsoil with different passes of consolidation injections. The injection material depends on the lithological morphology of the soil to be consolidated. Due to the type of subsoil in this case, as well as the material's low cost and ease of use and control, this paper proposed injections of controlled cement grout [78,79]. Synthetic resin is frequently used as an injection fluid, though it does not allow for high solicitation [52]. Three beneficial effects of injecting cement grout into the subsoil have been observed: (1) filling existing gaps, (2) soil compaction, and (3) interstitial water reduction and/or elimination. 


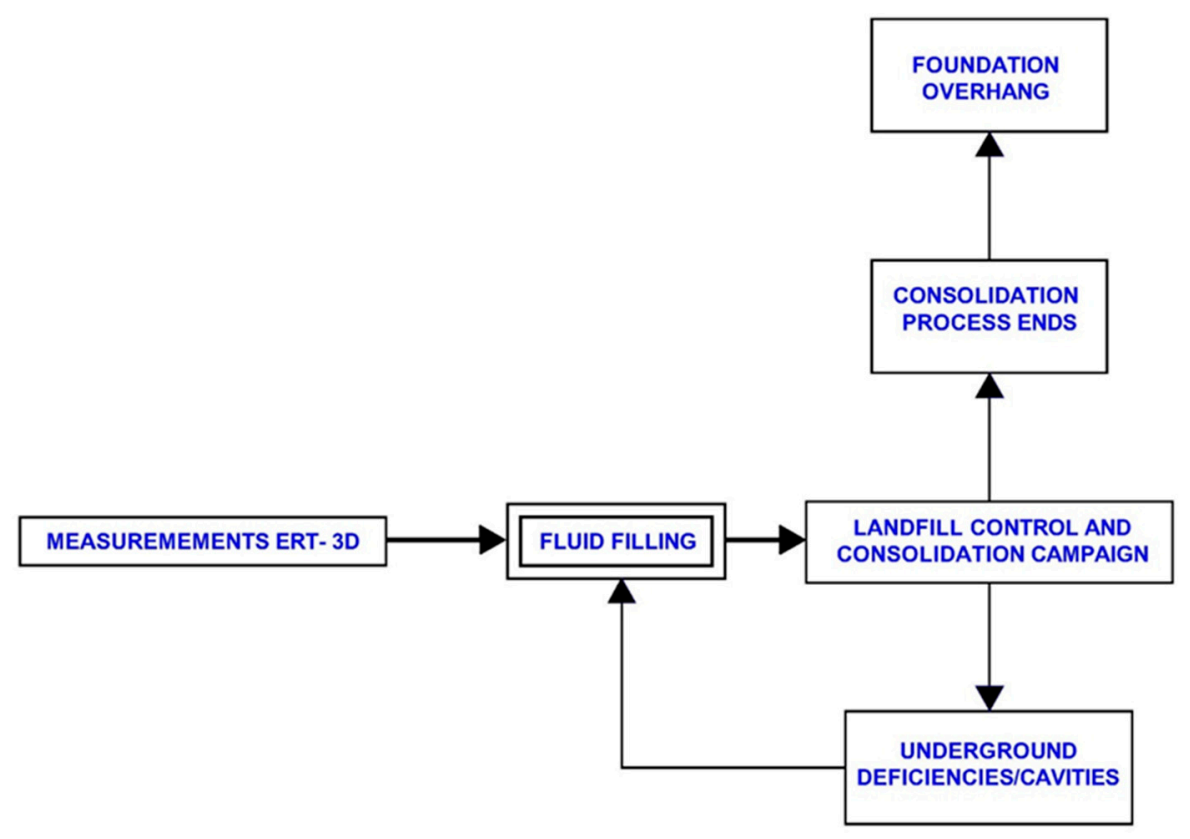

Figure 5. Block-flow diagram, showing the phases and methodology developed for intervening with the subsoil under the foundations of buildings with differential settlements.

\subsection{Approach Methodology: Application}

Had the proposed methodology not been applied in this case, the building could have been damaged to a critical point, making its repairs too expensive to pursue. Other, more invasive proceedings, such as underpinning through micropyles [5,80-82], were not feasible due to the state of the building and the structural typology of the load-bearing walls. However, making consolidation injections into the subsoil allowed recovery, to a certain degree, of the differential settlement suffered and rendered the building useable again.

The first necessary action involved using electrical tomography to analyze the subsoil beneath the affected foundations. In an initial campaign, this study accomplished various tests with spacings of $0.80,1.00$, and $1.50 \mathrm{~m}$ to identify the best resolution for checking the subsoil's state. A spacing of $0.80 \mathrm{~m}$ was chosen, based on another recent research [11].

The Syscal Switch 48 (V114 ++) from IRIS Instruments was used as electrical tomography equipment. It is a multi-electrode piece of equipment with an integrated computer capable of managing up to 900 electrodes, with resolution characteristics of resolution/accuracy: $1 \mu \mathrm{V} / 0.2 \%$ [43]. The equipment power source is $250 \mathrm{~W}$ and $2.5 \mathrm{~A}$, which generates $880 \mathrm{Vp}-\mathrm{p}$ pulses, and the manufacturer has incorporated a transmitter and receiver into the system. Among the equipment's features are a time injection adjustment, an apparent resistivity and chargeability automatic processor, a 3D real-time resistivity control, a voltage and current injection curve control, an integrated PC, and a commutation processor. The locations of the two topographies' parallel profiles (E1-E2) were shown via coordinates given by a GPS from Garmin Etrex Ventura [14], with a WG84 coordinate system. The results are listed in Table 3.

In the developed methodology, two parallel profiles (E1 and E2) were selected, covering an area of approximately $240 \mathrm{~m}^{2}$, which included the main affected building area in accordance with Figure 6 and Table 3. The electrodes were placed in parallel.

RES3DINV-3D data inversion software for electrical imaging and induced polarization (IP) [83] — was used to automatically invert the acquired data from apparent resistivity and produce a 3D resistivity model. The two parallel profiles were executed using a dipole-dipole matrix. The dipole-dipole matrix was chosen due to its sensitivity to lateral variations of resistivity $[41,84]$; thus, structures such as gaps and cavities that were damaging the building's subsoil could be detected. This dipole-dipole matrix provided us with a sharper horizontal resolution of the whole, which is an important advantage in this type of 
building pathology. As discussed previously, an inter-electrode separation of $0.80 \mathrm{~m}$ was estimated as suitable for this methodology. The two profiles extended along $28 \mathrm{~m}$, with 72 electrodes distributed according to the coordinates listed in Table 3 and Figure 6.

Table 3. UTM coordinates of the tomography profiles; location of the profiles according to the distribution of Figure 6.

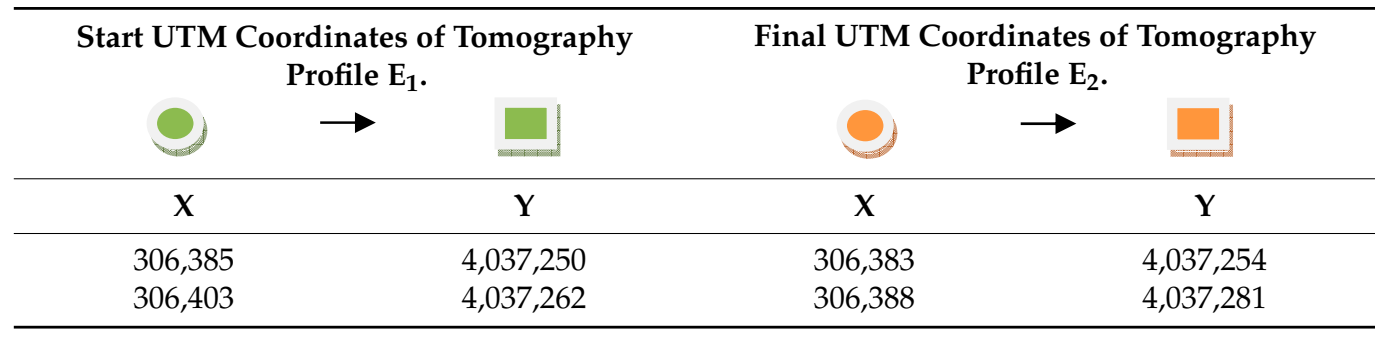

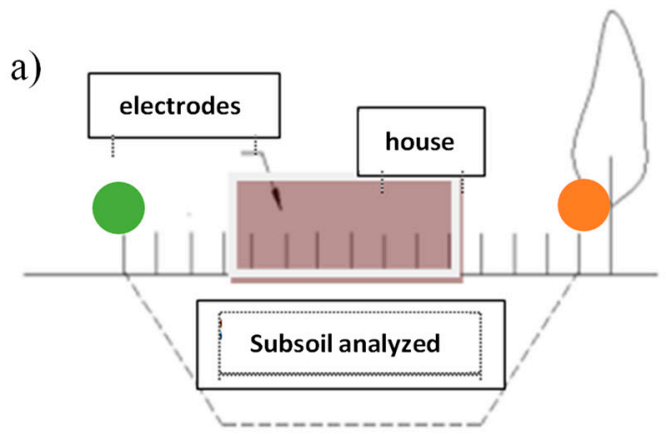

b)

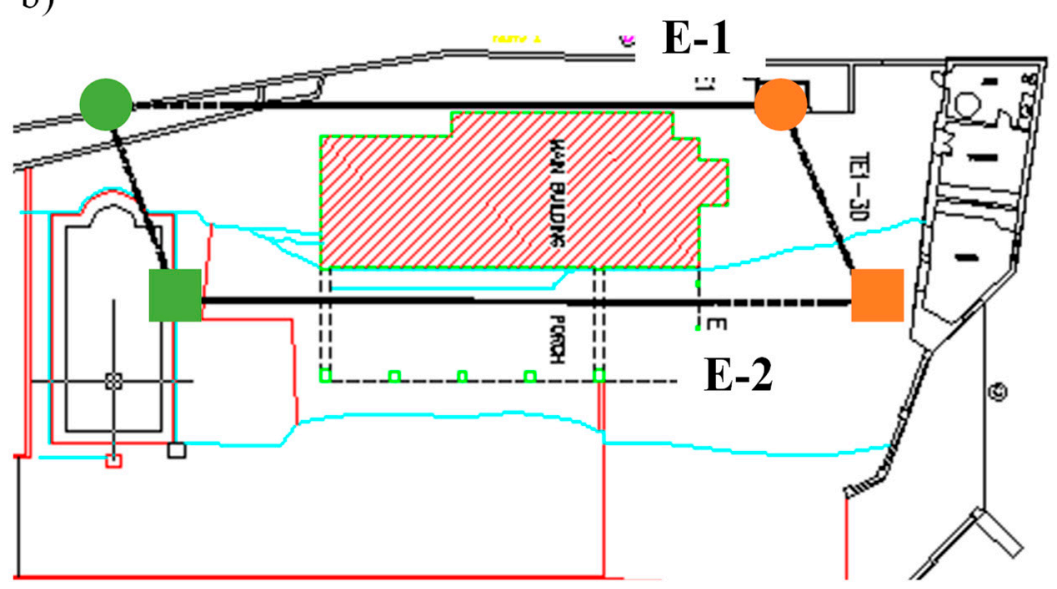

Figure 6. (a) Longitudinal scheme of the methodology and installation of the electrodes at $0.80 \mathrm{~m}$ in the building (house), as well as the subsoil analyzed with ERT -3D. The analyzed subsoil has a depth of $5.80 \mathrm{~m}$, which corresponds to levels I and II of the geotechnical layers detected. (b) ERT -3D (TE1-3D) delimited tomography surface, covering the main building's foundation structure, within the parallel profiles proposed: E1 and E2. Circles refer to the E1 profile, while squares refer to E2; orange refers to the initial UTM coordinates, while green refers to the final ones (Table 3).

Figure 7 shows a 3D electrical resistivity model from the studied terrain and the depths reached, in this case, up to $5.80 \mathrm{~m}$ depth. Both profiles show resistivity values represented in a range of colors for better and easier observation of the variations in subsoil vertical and horizontal resistivities. Zones with resistivity values between $0-55 \Omega$ $\mathrm{m}$ corresponded to levels of clay or colluvial material, represented in green; zones between 55-1000 $\Omega \mathrm{m}$, shown in orange, corresponded to fillings or colluvium removed with low 
compactness; and resistivity $>1000 \Omega \mathrm{m}$, in red, indicated anomalies due to the presence of interstitial gaps.

\section{Slices of Inverted Resistivity}

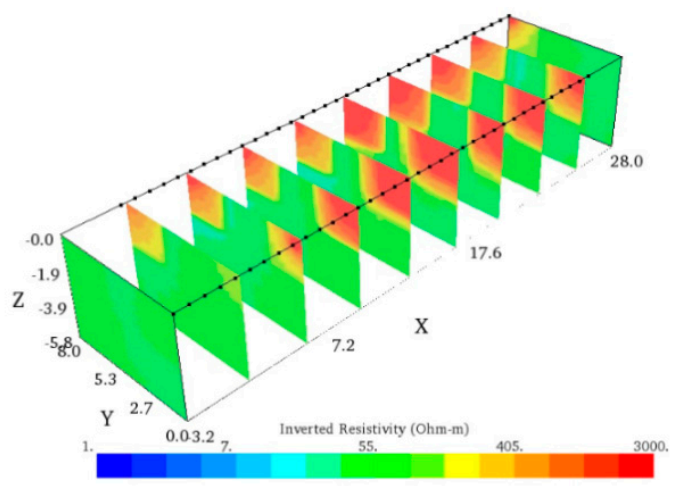

Figure 7. Advanced inversion algorithm of 3D synthetic data (RES3DINV software). Electric Ground Section ERT-3D: cross-section diagram of the ground, with the probable behavior of the soil and foundation. Cross-section scheme, with the likely behavior of the soil and foundation.

Figure 7 shows resistivity anomalies presented in slices of subsoil supporting the foundation of the damaged building. The red color shows a higher resistivity value, up to $3000 \Omega \mathrm{m}$, which suggests that there are cavities causing the resistivity to rise. From the obtained resistivities, combined with the geotechnical data (SPT standards) $[85,86]$, the physicochemical properties of geological materials can be determined.

The survey depth was established as $5.80 \mathrm{~m}$, considering the previous geotechnical results of Table 1. From that depth, level III began to appear, determined by a rocky matrix of phyllite. The main anomalies were located on the main load-bearing walls, specifically $\mathrm{A}$ and $\mathrm{B}$.

The structure of the building had been seriously damaged by the seat of its foundation and the turning of the building, specifically in the main facade between pilasters and the main bearing wall (wall B). There were also apparent interstitial anomalies in the subsoil up to $3.90 \mathrm{~m}$ deep in the dielectric profile E2 (wall B), and $2.00 \mathrm{~m}$ in the dielectric profile E1 (wall A). The anomalies and settlement in the foundation of wall B (S2) were of greater importance than the settlement at the base of wall A (S1), with a characteristic angular distortion of $\beta=0.0086$, hence the forward inclination of the building. In summary, according to the algorithm developed in Figure 6, the first phase of the tomographical campaign was carried out, by analyzing the resistivities of the subsoil supporting the building and considering previous data, including the initial geotechnical data. Anomalies and areas with low compaction and/or gaps were identified and isolated in ERT-3D for the building's main load-bearing walls (Figure 8), so this knowledge might be acted on in the future.

Given the powerful information about the subsoil under the building's main loadbearing walls, the second phase of this methodology was proposed: consolidation injections into the subsoil for those detected anomalies (flow diagram, Figure 5). Figure 9 isolates the areas to be treated with injections via the RES3DINV investment program.

The damages observed in the analyzed building and the initial geotechnical tests confirmed the diagnosis from the ERT-3D tomography methodology. The initial ERT-3D results - that is, the application of the first phase of the flow chart (Figure 5) - showed high coincidence in the geological composition of the supporting subsoil beneath the damaged building: altered clay edges and colluvial sand from the meteorisation of the rock matrix (phyllite).

This innovative intervention technique allowed the researchers to evaluate the induced effects in the field and, in light of them, carry out possible modifications in the distribution 
of injection points to consolidate the subsoil. In the procedure's second phase, after the injections in the anomalies were made, the ERT-3D contrast was repeated to check the consolidation results.

\section{Inverted Resistivity Image}
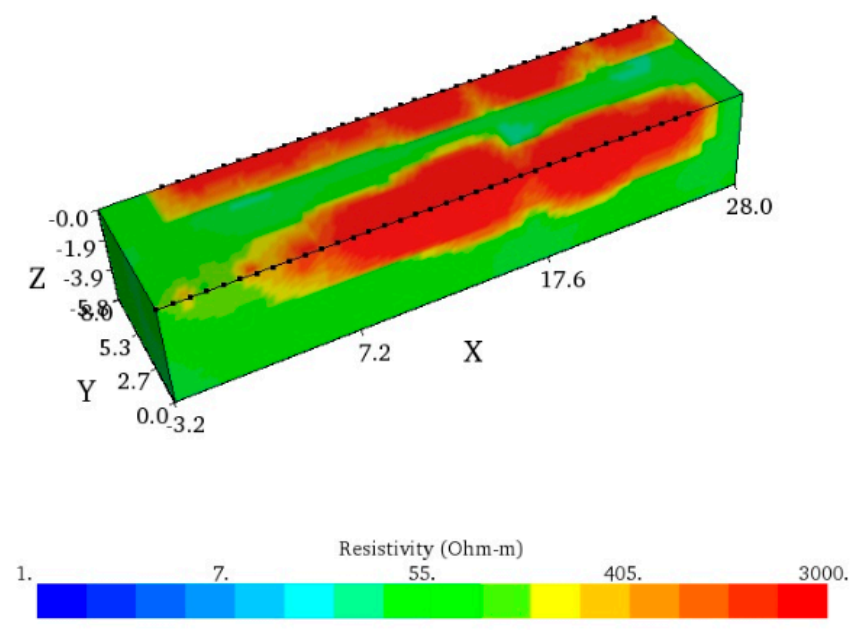

Figure 8. Volume plot rendered for the subsoil model of the building analyzed with topography included results of 3D inversion of electrical resistivity tomography over the whole survey area. On the left, view from the south, and, on the right, view from the north.

a)

3D Resistivity Contour Plot

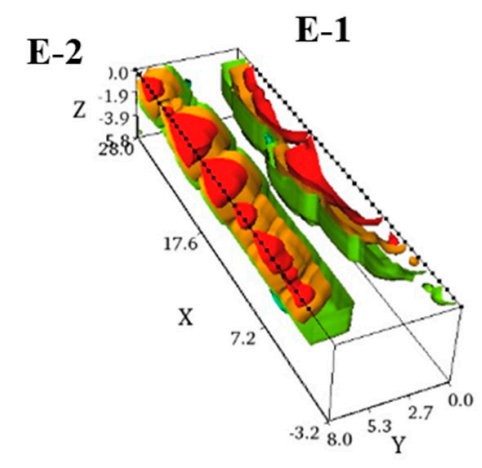

b)

\section{D Resistivity Contour Plot}

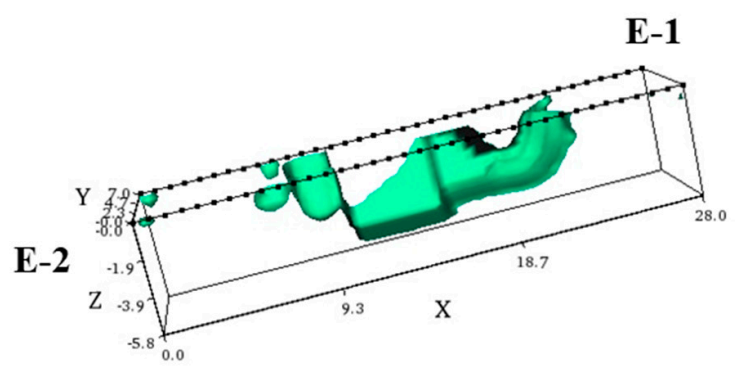

Figure 9. Example of a 3D survey using the offset dipole-dipole: (a) resistivity contour plot by anomalies. Scheme obtained through ERT-3D. (b) Resistivity contour plot by anomalies. Isolation of areas to be treated with soil consolidation injections grout using RES3DINV software.

The second phase of the proposed procedure (Figure 5) intended to obtain uniformity of chemical and physical features in the stabilized subsoil $[65,70,86]$ until the desired goal was reached. As shown in Figure 10, the contrast tomography gave a favorable result after the cement grout injections were applied. The resistivities up to $3000 \Omega \mathrm{m}$ that caused distortions (cavities), affecting the stability of the building in Figure 8, were generally reduced drastically, even at values below $55 \Omega \mathrm{m}$. This means the anomalies and stability issues of the building were resolved. In this way, the affected building could be recovered, and demolition avoided. 


\section{Inverted Resistivity Image}
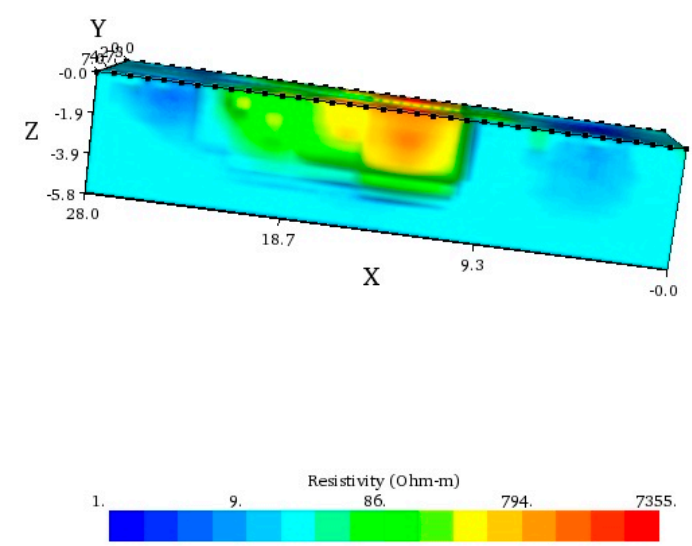

Figure 10. Results of 3D inversion of electrical resistivity tomography over the whole survey area. On the left, view from the south, and, on the right, view from the north. Contrast tomography after the consolidation injections in the subsoil.

The proposed intervention methodology is, therefore, highly effective in buildings damaged by settlements in shallow foundations, due to a deficient stress capacity of the subsoil, in this case by a removed anthropic fill. In this case study, a building on the verge of collapse, was recovered. Figure 10, showing the tomography performed after consolidation injections, indicates that up to $3000 \Omega \mathrm{m}$ resistivity anomaly areas have disappeared and left the building's subsoil consolidated and stabilized.

Four beneficial effects of our combined interactive methodology (tomography-injection) have been observed on subsoil where a building foundation rests:

(1) Fills existing gaps improving its bearing capacity.

(2) $100 \%$ subsoil compaction.

(3) Reduces and/or eliminates interstitial water in subsoil gaps.

(4) Recovery of severely damaged buildings with hardly any collateral effects.

\section{Results and Discussion}

The interpretation and adaptation of this paper's proposed methodology were satisfactory and successful. The building, on the verge of collapse, recovered its stability and was ready for use again. This procedure is promising for buildings that have reached their ultimate limit state but must be maintained either because they could not be rebuilt due to urban regulations (as in this case), or because they are listed as historic and cultural heritage buildings to be preserved at all costs.

The advantage of this proposed method is that ERT-3D allows researchers to determine if the foundation settlement and subsidence of the subsoil has been permanently eliminated after consolidation injections. Consolidating foundations through grout injections is inherently problematic because researchers do not know how much injection grout or how many injections are necessary, and they are unable to control or physically see the result, as it is underground. Therefore, an intervention methodology, such as the one presented here uniting ERT-3D monitoring with the consolidation injection process, is essential for checking the results. The advantage of this ERT-3D methodology, as well as consolidation grout injection compared to other reclining systems (e.g., micropyles), is that it is a non-invasive method for an already damaged building. This makes the system useful in extreme cases, like the one analyzed here.

In the application of our methodology, two electrical profiles were made, E1 and E2 (Figure 6), an upper part of approximately $3.90 \mathrm{~m}$ thick was defined for E2 (wall B) and 
$2.00 \mathrm{~m}$ for E1 (wall A) with high resistivity, ranging from 500 to up to $3000 \Omega \mathrm{m}$. This section corresponded to the colluvial material (porous) that covers the metamorphic rock (phyllites). Under this lithology was the rocky matrix, formed by altered phyllites with less resistivity, of the order of $55 \Omega \mathrm{m}$. The upper colluvial material, which was in contact with the underside of the building's footings, showed a significant degree of alteration, which means a high resistivity (from 1000 to up to $3000 \Omega \mathrm{m}$ ). However, the resistivity values were quite variable within this mass of colluvial material, and this is linked to two causes: (1) lack of compaction and (2) presence of gaps and cavities in the subsoil where the foundation of the building supported, which coincided with the levels I and II altered. These data confirm the instability results of the shallow foundation of the building. The building's final state, after the application of this methodology, is shown in Figure 11.

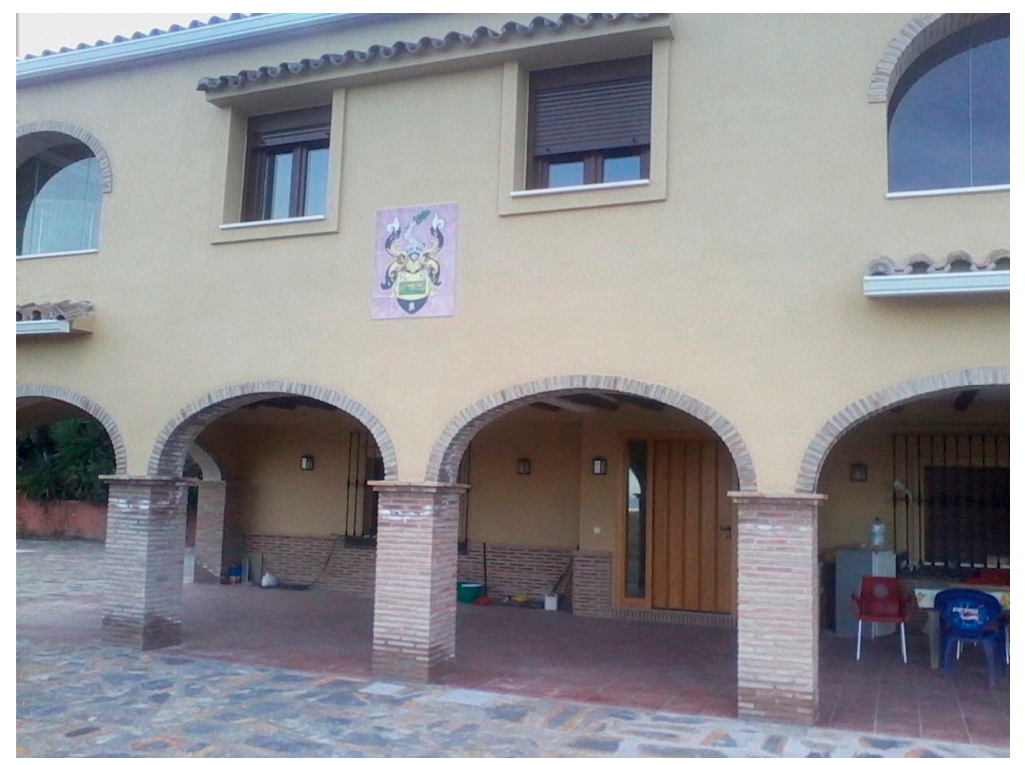

Figure 11. Current state of the main building. Image taken after the intervention and application of the methodology. Had this methodology not been used, the only solution would have been demolition of the building.

\section{Conclusions and Follow-Up}

The ERT-3D technique proposed in this research proved to be versatile, fast, and cost-effective for detecting subsurface anomalies. In the present case study, the researchers were able to analyze the subsurface to a depth of $5.80 \mathrm{~m}$, deep below the severely damaged building. Nevertheless, anomalies only existed at a depth of $3.90 \mathrm{~m}$, below the foundation of load-bearing wall B. When the subsoil has holes, those spaces are filled with air or with water which, when evaporated, are dielectric. This means that the terrain presents a strong gradient anomaly and very high resistivity values, which causes serious damage to the foundation and structure of the building. Our methodology solves this problem, by reducing the resistivity of these initial anomalies (cavities) by means of the combined grout injection in two passes, with the control of resistivities through 3D tomography, and returning the stabilization of the foundation of the building in a non-invasive way. It has been applied to a case study that has been totally effective, where initially we had resistivities up to $3000 \Omega \mathrm{m}$ and it was effectively reduced with our methodology to $55 \Omega \mathrm{m}$.

In the present case study, to implement the methodology, the subsoil cavities and weaknesses were first identified and located beneath the building's foundations. Secondly, a consolidation grout injection campaign was carried out, enhancing the subsoil conditions to an optimum result. The consolidation fluid injections eliminated the high value of initial subsoil resistivities (up to $3000 \Omega \mathrm{m}$ ) and moved those resistivities to values between 55 and $1000 \Omega \mathrm{m}$, filling in those cavities. Through this process, ERT-3D showed itself to be a fundamental, minimally invasive tool for research. It was useful both during the project 
phase and in the follow-up, underpinning work when the consolidation injections were placed under the foundations.

The limitations of our methodology increase with the depth of the altered subsoil, from $5.80 \mathrm{~m}$. As has been shown in our research, it is difficult to have a reliable electrical section of resistivities to intervene later with consolidation injections. Although it would be necessary to use another geophysical methodology and another type of deep consolidation intervention using a pile or micropyle, our methodology is appropriate for emergency surface consolidations in disturbed porous subsoils. As they work safely outside the affected building, this methodology offers researchers an accurate lithological model and correctly highlights subsurface anomalies. Hence, ERT-3D allows them to determine the causes of the instability of the foundation and building and how it can be later consolidated and stabilized, in addition to monitoring the chosen solution.

Author Contributions: Conceptualization, A.G.-M. and R.C.; methodology, A.G.-M.; software, A.G.-M. and M.F.-H.; validation, A.G.-M., J.I.Y. and M.F.-H.; formal analysis, A.G.-M. and M.F.H.; investigation, A.G.-M., J.I.Y. and R.C.; writing-original draft preparation, A.G.-M. and R.C.; writing-review and editing, R.C., A.G.-M.; visualization, R.C. and M.F.-H.; supervision, R.C. All authors have read and agreed to the published version of the manuscript.

Funding: This research received no external funding.

Data Availability Statement: Some or all data, models, or approach that support the findings of this study are available from the corresponding author upon reasonable request.

Conflicts of Interest: The authors declare no conflict of interest.

\section{References}

1. Keller, G.V.; Frischknecht, F.C. Electrical Methods in Geophysical Prospecting; Pergamon Press: Oxford, UK, 1966.

2. Nobahar, A.; Popescu, R. Some effects of soil heterogeneity on bearing capacity of shallow foundations. In Proceedings of the ASCE Special Conference, Houston, TX, USA, 10-13 September 2001.

3. González de Vallejo, L.; Ferrer, M.; Ortuño, L.; Oteo, C. Ingeniería Geológica; Prentice Hall: Madrid, Spain, 2002.

4. Ede, A.N. Building collapse in Nigeria: The trend of casualties in the last decade (2000-2010). Int. J. Civ. Environ. Eng. 2010, 10, 32-42.

5. Gutiérrez-Martín, A. El Agua de Infiltración de Lluvia, Aagente Desestabilizador de Taludes en la Provincia de Málaga. Modelos constitutivos. Ph.D. Thesis, University of Granada, Granada, Spain, 2016.

6. Olayanju, G.M.; Mogaji, A.K.; Lim, H.S.; Ojo, T.S. Foundation integrity assessment using integrated geophysical and geotechnical techniques: Case study in crystalline basement complex, southwestern Nigeria. J. Geophys. Eng. 2017, 14, 675-690. [CrossRef]

7. Fishman, Y.A. Effect of geological factors upon the pattern of failure and the stability of rock foundations of concrete dams. Bull. Int. Assoc. Eng. Geol. 1979, 20, 18-20. [CrossRef]

8. Terzaghi, K.; Peck, R.B.; Mesri, G. Soil Mechanics in Engineering Practice, 3rd ed.; John Wiley Sons Inc.: Hoboken, NJ, USA, 1996.

9. El-Kateb, T.; Chalaturnyk, R.; Robertson, P.K. An overview of soil heterogeneity: Quatification and implications on geotechnical field problems. Can. Geotech. J. 2003, 40,1-15. [CrossRef]

10. Cho, S.E. Effects of spatial variability of soil properties on slope stability. Eng. Geol. 2007, 92, 97-109. [CrossRef]

11. Olarte, J.; Dashti, S.; Liel, A.B. Can ground densification improve seismic performance of the soil-foundation-structure system on liquefiable soils? Earthq. Eng. Struct. Dyn. 2018, 47, 1193-1211. [CrossRef]

12. Fagbenle, O.I.; Oluwunmi, A.O. Building failure and collapse in Nigeria: The influence of the informal sector. J Sustain. Dev. 2010, 3, 268-276.

13. Olofsson, B.; Jernberg, H.; Rosenqvist, A. Tracing leachates at waste sites using geophysical and geochemical modelling. Environ. Earth Sci. 2006, 49, 720-732. [CrossRef]

14. Osinowo, O.O.; Akanji, A.O.; Akinmosin, A. Integrated geophysical and geotechnical investigation of the failed portion of a road in Basement Complex terrain, southwestern Nigeria. RMZ-Mater. Geoenviron. 2011, 58, 143-162.

15. Loke, M.H.; Barker, R.D. Practical techniques for 3D resistivity surveys and data inversion. Geophys. Prospect. 1996, 44, 449-523. [CrossRef]

16. Ogilvy, R.; Meldrum, P.; Chambers, J.; Williams, G. The use of 3D electrical resistivity tomography to characterize waste and leachate distributions within a closed landfill, Thriplow, UK. J. Environ. Eng. Geophys. 2002, 7, 11-18. [CrossRef]

17. Aizebeokhai, A.P.; Olayinka, A.I.; Singh, V.S. Numerical evaluation of 3D geoelectrical resistivity imaging for environmental and engineering investigations using orthogonal 2D profiles. In SEG Technical Program Expanded Abstracts 2009; Society of Exploration Geophysicists: New York, NY, USA, 2009. [CrossRef] 
18. Arango-Galván, C.; De la Torre-González, B.; Chávez-Segura, R.E.; Tejero-Andrade, A.; Cifuentes-Nava, G.; Hernández-Quintero, E. Structural pattern of subsidence in an urban area of the southeastern Mexico Basin inferred from electrical resistivity tomography. Geofísica Int. 2011, 50, 401-409. [CrossRef]

19. Cardarelli, E.; Di Filippo, G.; Tuccinardi, E. Electrical resistivity tomography to detect buried cavities in Rome: A case study. Near Surf. Geophys. 2006, 4, 387-392. [CrossRef]

20. Argote-Espino, D.; Tejero-Adrade, A.; Cifuentes-Nava, G.; Iriarte, L.; Farías, S.; Chávez, R.E.; López, F. 3D electrical propespection in the archaeological site El Pahu, Hidalgo State, Central Mexico. J. Archaeol. Sci. 2013, 40, 1213-1223. [CrossRef]

21. Chávez, R.E.; Cifuentes-Nava, G.; Tejero, A.; Hernández-Quintero, J.E.; Vargas, D. Tomografía de resistividad eléctrica 3D (ERT) especial aplicada para detectar fracturas enterradas en áreas urbanas: San Antonio Tecomal, Milpa Alta, México. Geofísica Int. 2014, 53-54, 425-434. [CrossRef]

22. Vanhove, Y.; Wang, M.; Wieczorowski, M.; Mathia, T.G. Metrological perspectives of tomography in civil engineering. In Proceedings of the 6th World Congress on Industrial Process Tomography, Beijing, China, 6-9 September 2010.

23. Schabowicz, K.; Hola, J. Nondestructive elastic-wave test of foundation slab in office building. Mater. Trans. 2012, 53, 296-302. [CrossRef]

24. Hola, J.; Schabowicz, K. State-of-the-art non-destructive methods for diagnostic testing of building structures-anticipated development trends. Arch. Civil Mech. Eng. 2010, 10, 5-18. [CrossRef]

25. Matawal, D.S. The challenges of building collapse in Nigeria. In Proceedings of the National Technical Workshop on Building Collapse in Nigeria, Akure, Nigeria, 12-14 November 2012; pp. 3-54.

26. Choi, P.; Kim, N.-H.; Lee, B.-H.; Won, M.C. Application of ultrasonic shear-wave tomography to identify horizontal crack or delamination in concrete pavement and bridge. Constr. Build. Mater. 2016, 121, 81-91. [CrossRef]

27. Palacky, G.V. Resistivity Characteristics of Geologic Targets. Electromagn. Methods Appl. Geophys. 1988, 1, 52-129. [CrossRef]

28. Putiska, M.; Nikolaj, M.; Dostal, I.; Kusnirak, D. Determination of cavities using electrical resistivity tomography. Contrib. Geophys. Geod. 2012, 42, 201-211. [CrossRef]

29. Aizebeokhai, A.P.; Olayinka, A.I.; Singh, V.S. Application of 2D and 3D geolectrical resistivity imaging for engineering site investigation in a crystalline basement terranin, southwestem Nigeria. Environ. Earth Sci. 2010, 61, 1481-1492. [CrossRef]

30. Peng, A.; Aijun, Z.; Yichuan, X.; Bo, Z.; Wenyuan, R. Experimental study on settling characteristics of thick self-weight collapsible loess in Xinjiang Ili region in China using field immersion test. Soils Found. 2018, 55, 1476-1491.

31. Shogaki, T.; Fujii, Y.; Nakagawara, Y. Deformation of the foundation and structure of Tomioka Silk Mill's East Cocoon Warehouse. Soils Found. 2019, 59, 789-800. [CrossRef]

32. Youssef, A.M.; Pradhan, B.; Sabtan, A.A.; El-Harbi, H.M. Coupling of remote sensing data aided with field investigations for geological hazards assessment in Jazan area, Kingdom of Saudi Arabia. Environ. Earth Sci. 2011, 65, 119-130. [CrossRef]

33. Loke, M.H. Electrical Imaging Surveys for Environmental and Engineering Studies, a Practical Guide to 2D and 3D Surveys. Available online: https:/ / pages.mtu.edu/ \{\}ctyoung/LOKENOTE.PDF (accessed on 11 January 2021).

34. Loke, M.; Chambers, J.; Rucker, D.; Kuras, O.; Wilkinson, P. Recent developments in the direct-current geoelectrical imaging method. J. Appl. Geophys. 2013, 95, 135-156. [CrossRef]

35. Olvera-Ramírez, A.B.; Chávez, R.E.; Hernández-Quintero, J.E. Detección de zonas de fracturamiento en áreas urbanas mediante el método capacitivo de tomografía eléctrica. Rev. Geofísica 2014, 64, 129-142. [CrossRef]

36. Loke, M.H. Tutorial: 2-D and 3-D Electrical Imaging Surveys. Available online: http://personales.upv.es/jpadin/coursenotes.pdf (accessed on 12 January 2021).

37. Fernández, G.; Teixidó, T.; Peñab, J.A.; Burilloa, F.; Claros, J. Using shallow geophysical methods to characterise the monumental building at the Segeda I site (Spain). J. Archaeol. Sci. Rep. 2015, 2, 427-436. [CrossRef]

38. Badmus, B.S.; Akinyemi, O.D.; Olowofela, J.A.; Folarin, G.M. 3D electrical resistivity tomography survey for the basement of the Abeokuta terrain of Southwestern Nigeria. J. Geol. Soc. India 2012, 80, 845-854. [CrossRef]

39. Dahlin, T.; Bernstone, C. A Roll-Along Technique for 3D Resistivity Data Acquisition with Multi-Electrode Arrays. In Proceedings of the 10th EEGS Symposium on the Application of Geophysics to Engineering and Environmental Problems, Reno, NV, USA, 23-26 March 1997.

40. Day-Lewis, F.D.; White, E.A.; Johnson, C.D.; Lane, J.W.; Belaval, M. Continuous resistivity profiling to delineate submarine groundwater discharge-examples and limitations. Lead. Edge 2006, 25, 724-728. [CrossRef]

41. Clément, R.; Descloitres, M.; Günther, T.; Oxarango, L.; Morra, C.; Laurent, J.-P.; Gourc, J.-P. Improvement of electrical resistivity tomography for leachate injection monitoring. Waste Manag. 2010, 30, 452-464. [CrossRef]

42. Xiao, X.-H.; Xiao, P.-W.; Dai, F.; Li, H.-B.; Zhang, X.-B.; Zhou, J.-W. Large Deformation Characteristics and Reinforcement Measures for a Rock Pillar in the Houziyan Underground Powerhouse. Rock Mech. Rock Eng. 2017, 51, 561-578. [CrossRef]

43. Loke, M.H. RES3DMOD Ver. 2.1 M.H. Loke. Available online: www.geoelectrical.com (accessed on 24 September 2015).

44. Ward, S.H.; Fraser, D.C. Conduction of electricity in rocks. In Mining Geophysics; Society of Exploration Geophysicists: Houston, TX, USA, 1967; Volume 2, pp. 197-223.

45. Zonge, K.L. Electrical Parameters of Rocks as Applied to Geophysics. Ph.D. Thesis, The University of Arizona, Tucson, AZ, USA, 1972.

46. Utset, A.; Castellanos, A. Drainage effects on spatial variability of soil electrical conductivity in a vertisol. Agric. Water Manag. 1999, 38, 213-222. [CrossRef] 
47. Carroll, Z.L.; Oliver, M.A. Exploring the spatial relations between soil physical properties and apparent electrical conductivity. Geoderma 2005, 128, 354-374. [CrossRef]

48. Jiménez Salas, J.A.; Justo Alpañes, J.L. Geotecnia y Cimientos II-III; Rueda: Madrid, Spain, 1981.

49. Ni, J.C.; Cheng, W.-C. Using fracture grouting to lift structures in clayey sand. J. Zhejiang Univ. A 2010, 11, 879-886. [CrossRef]

50. Kumari, D.; Xiang, W.-N. Review on biologically based grout material to prevent soil liquefaction for ground improvement. Int. J. Geotech. Eng. 2019, 13. [CrossRef]

51. Liu, Y.; Chang, C.-W.; Namdar, A.; She, Y.; Lin, C.-H.; Yuan, X.; Yang, Q. Stabilization of expansive soil using cementing material from rice husk ash and calcium carbide residue. Constr. Build. Mater. 2019, 221,1-11. [CrossRef]

52. Uretek Engineering: Stabilization of Soils and Buildings by Expansive Resin Injections. Available online: http//www.uretek.es (accessed on 5 September 2019).

53. Parasnis, D.S. Principles of Applied Geophysics, 5th ed.; Chapman \& Hall: London, UK; New York, NY, USA, 1997.

54. De Groot-Hedlin, C.; Constable, S. Occam's inversion to generate smooth, two-dimensional models form magne-totelluric data. Geophysics 1990, 55, 1613-1624. [CrossRef]

55. Sasaki, Y. Resolution of Resistivity Tomography Inferred from Numerical Simulation. Geophys. Prospect. 1992, 40, 453-463. [CrossRef]

56. Loke, M.; Acworth, I.; Dahlin, T. A comparison of smooth and blocky inversion methods in 2D electrical imaging surveys. Explor. Geophys. 2003, 34, 182-187. [CrossRef]

57. Loke, M.H.; Dhalin, T. A comparison of the Gauss-Newton and quasi-Newton methods in resistivity imaging inversion. J. Appl. Geophys. 2002, 49, 149-162. [CrossRef]

58. Chambers, J.E.; Meldrum, P.I.; Gunn, D.A.; Wilkinson, P.B.; Kuras, O.; Weller, A.L.; Ogilvy, R.D. Hydroge-ophysical Monitoring of Landslide Processes Using Automated Time-Lapse Electrical Resistivity Tomography (ALERT). In Proceedings of the Near Surface-15th European Meeting of Environmental and Engineering Geophysics, Dublin, Ireland, 7-9 September 2009.

59. Niesner, E. Subsurface resistivity changes and triggering influences detected by continuous geoelectric monitoring. Lead. Edge 2010, 29, 952-955. [CrossRef]

60. de Bari, C.; Lapenna, V.; Perrone, A.; Puglisi, C.; Sdao, F. Digital photogrammetric analysis and electrical resistivity tomography for investigating the Picerno landslide (Basilicata region, southern Italy). Geomorphology 2011, 133, 34-46. [CrossRef]

61. Loke, M.; Dahlin, T.; Rucker, D.F. Smoothness-constrained time-lapse inversion of data from 3D resistivity surveys. Near Surf. Geophys. 2013, 12, 5-24. [CrossRef]

62. Gutiérrez-Martín, A. A GIS-physically-based emergency methodology for predicting rainfall-induced shallow landslide zonation. Geomorphology 2020, 359, 107121. [CrossRef]

63. Herrada, M.A.; Gutiérrez-Martin, A.; Montanero, J.M. Modeling infiltration rates in a saturated/unsaturated soil under the free draining condition. J. Hydrol. 2014, 515, 10-15. [CrossRef]

64. Gutiérrez-Martín, A.; Herrada, M.Á.; Yenes, J.I.; Castedo, R. Development and validation of the terrain stability model for assessing landslide instability during heavy rain infiltration. Nat. Hazards Earth Syst. Sci. 2019, 19, 721-736. [CrossRef]

65. Jiménez Montoya, P.; García Meseguer, A.; Moran Cabre, F. Hormigón Armado; Gustavo Gili Editorial: Barcelona, Spain, 2010.

66. Burland, J.B.; Wroth, C.P. Settlement of Buildings and Associated Damage; Pentech Press: London, UK, 1974.

67. Burland, J.B.; Broms, B.; De Mello, V.F.B. Behaviour of foundations and structures. State of Art. Report. Session 2. In Proceedings of the Ninth Conference on Soil Mechanics and Foundation Engineering, Tokyo, Japan, 10-15 July 1977; p. 495.

68. Boscardin, M.D.; Cording, E.J. Building Response to Excavation-Induced Settlement. J. Geotech. Eng. 1989, 115, 1-21. [CrossRef]

69. Dimmock, P.S.; Mair, R.J. Effect of building stiffness on tunnelling-induced ground movement. Tunn. Undergr. Space Technol. 2008, 23, 438-450. [CrossRef]

70. Rodríguez Ortiz, J.M. Cursoaplicado de Cimentaciones; Servicio de Publicaciones del Colegio Oficial de Arquitectos: Madrid, Spain, 1982.

71. Negulescu, C.; Foerster, E. Parametric studies and quantitative assessment of the vulnerability of a RC frame building exposed to differential settlements. Nat. Hazards Earth Syst. Sci. 2010, 10, 1781-1792. [CrossRef]

72. Sanabria, M.P.; Guardiola-Albert, C.; Tomás, R.; Herrera, G.; Prieto, A.; Sánchez, H.; Tessitore, S. Subsidence activity maps derived from DInSAR data: Orihuela case study. Nat. Hazards Earth Syst. Sci. 2014, 14, 1341-1360. [CrossRef]

73. Meyerhof, G.G. The settlement analysis of building frames. Struct. Eng. 1947, 25, 369-409.

74. Burland, J.B. The assessment of the risk of damage to buildings due to tunnelling and excavation. In Proceedings of the Second International Conference on Soil Structure Interaction in Urban Civil Engineering, Planning and Engineering for the Cities of Tomorrow, Zurich, Switzerland, 7-8 March 2002; Volume 1.

75. Diaz, C.; Cornadó, C.; Santamaría, P.; Rosell, J.R.; Navarro, A. Actuación preventiva de diagnóstico y control de movimientos en los edificios afectados por subsidencia en el barrio de la Estación de Sallent (Barcelona). Inf. Construcción 2015, 67, 089. [CrossRef]

76. Hintze, S. Risk Analysis in Foundation Engineering with Application to Piling in Loose Friction Soils in Urban Situations. Ph.D. Thesis, Division of Soil and Rock Mechanics, Royal Institute of Technology, Stockholm, Sweden, 1994.

77. Malinin, A.; Gladkov, I.; Malinin, D. Experimental research of jet-grouting parameters in different soil conditions. In Proceedings of the Geo Shangai International Conference 2010, Shanghai, China, 3-5 June 2010. [CrossRef]

78. Argal, E.S. Modern Technologies and Problems of Ground Stabilization by Injection. Soil Mech. Found. Eng. 2020, 57, 219-226. [CrossRef] 
79. Bustamante, M. A Method for Calculating Anchors and Injected Micropiles; Bulletin of the SEMSC: Madrid, Spain, 1986; pp. 81-82.

80. Juran, I.; Bruce, D.A.; Dimillio, A.; Benslimane, A. Micropiles: The state of practice. Part II: Design of single micropiles and groups and networks of micropiles. Proc. Inst. Civ. Eng. Ground Improv. 1999, 3, 89-110. [CrossRef]

81. Pinyol, N.M.; Alonso, E. Design of micropiles for tunnel face reinforcement: Un drainedupper bound solution. J. Geotech. Geoenviron. Eng. 2012, 138, 89-99. [CrossRef]

82. Sastry, R.G.; Chahar, S.; Singh, M. Multiple regression analysis of geoelectric imaging and geotechnical site investigation test results. Curr. Sci. 2018, 114, 1946-1952. [CrossRef]

83. Seaton, W.J.; Burbey, T.J. Aquifer characterization in the Blue Ridge physiographic province using resistivity pro-filing and borehole geophysics: Geologic analysis. J. Environ. Eng. Geophys. 2000, 5, 45-58. [CrossRef]

84. Fletcher, G.F.A. Standar penetration test: Its uses and abuses. J. Soil Mech. Found. Div. 1965, 91. [CrossRef]

85. Inazumi, S. In-Situ Ground Surveying by the NSWS Testing Machine. Int. J. GEOMATE 2011, 1, 1-9. [CrossRef]

86. Yang, S.; Ren, X.; Zhang, J. Study on embedded length of piles for slope reinforced with one row of piles. J. Rock Mech. Geotech. Eng. 2011, 3, 167-178. [CrossRef] 